Journal of

Gender Studies

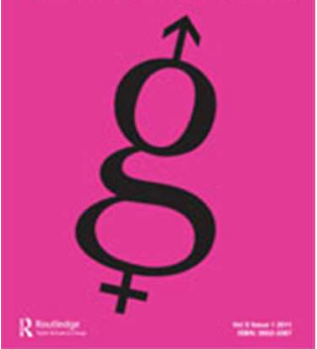

"Atheism is not the problem. The problem is being a woman" Atheist Women and Reasonable Feminism

\begin{tabular}{|r|l|}
\hline Journal: & Journal of Gender Studies \\
\hline Manuscript ID & CJGS-2018-0138.R1 \\
\hline Manuscript Type: & Research Articles \\
\hline Keywords: & atheism, feminism, gender, strength \\
\hline & \\
\end{tabular}

SCHOLARONE ${ }^{m}$

Manuscripts 


\title{
"Atheism is not the problem. The problem is being a woman" Atheist Women and Reasonable Feminism
}

\begin{abstract}
While the percentage of religiously unaffiliated women is growing in the West, little is known about the relationship between atheism and feminism. This article redresses the gap by exploring women's identification with atheism and feminism. The central argument draws on qualitative interview data from the UK, Australia, the US, and Poland and emphasizes the role of atheism as a background identity marker through which female subjectivity is enacted in everyday life. The findings are two-fold: first, atheism and feminism are both devalued identities when embraced by women; and second, identifying as an atheist affords the participants an impetus to invent a new vocabulary to account for their identity. In conclusion I argue that atheism provides a catalyst for the postfeminist discourse of independence, empowerment, and freedom of choice as the participants construct narratives of 'reasonable feminism'.
\end{abstract}

\section{Introduction}

Femininities in the new millennium are caught between old and new sets of cultural expectations. On the one hand, as intersectional feminist scholars have shown, femininity can no longer be analysed as a uniform category. On the other hand, the systemic structures which maintain the gender binary continue to affect gender identities and relations (Budgeon, 2014: 321; Ridgeway, 2011). As the cultural repertoire available for crafting feminine identities has expanded and diversified, traditional femininity has become a contested territory. One example of such contestation is the steady decline in the levels of women's religiosity in the West (Aune, Sharma, and Vincett, 2008; Brown, 2013). According to the Pew Research Forum, 'the religiously unaffiliated are growing among women at about the same rate as among men. Nearly one in five women (19\%) now describe themselves as religiously unaffiliated, up from $13 \%$ in 2007 ' (2015: 14). ${ }^{1}$ While women inhabit nonreligious culture in greater numbers, few openly declare themselves 'as convinced

\footnotetext{
${ }^{1}$ The report pertains to the U.S. data only. For a nuanced analysis of the gender gap in religiosity globally, see Pew Research Center 2016.
} 
atheists, even when they share a common attitude with atheists; namely that religions are harmful to societies, and religious beliefs are false from a scientific perspective. The forms of non-religiousness amongst these women varies from indifference on religious issues to extreme forms of atheism (Mahlamäki, 2012: np). This article captures the experiences of women who do identify as 'convinced atheists' but who do not regard themselves as activists, New Atheists, or even outspoken defenders of secularism. Neither are they unreservedly on board with the feminist cause. However, they all emphasise independence and strength as the guiding principles in their daily lives as 'everyday atheists' (Author, 2018).

The argument is structured as follows: first I outline the issues surrounding atheism and gender through examining the case of freethinking women of the nineteenth century; second, I turn to the relationship between atheism and feminism; third I provide methodological background to the study; fourth, atheist women's accounts of their identification with atheism and feminism are examined. I argue that self-identified atheist women embody a type of 'postfemininity' which cannot be neatly categorized, but which inevitably remains within the public gender regime (Walby, 2011). Open atheism as a lifestyle provides an example of fashioning novel ways of doing femininity in the postsecular world. The prioritization of 'strength' exemplifies the shift in the language of empowerment from the communityoriented to the self-governing individual. The strategies deployed by atheist women have a wider significance for the study of late modern femininities and their relationship to atheism. Atheism acts as a catalyst for a version of femininity which is non-compliant with the public gender regime (Budgeon, 2014: 319) in subtle and inconspicuous ways. The discussion fleshes out the ways in which atheism intersects with gender and feminism to create fresh ways of identity formation in the first quarter of the new millennium.

\section{Atheism, gender, and rebellion}

Atheism is gendered. As atheists account for a relatively small percentage globally (Lee, 2012: 591; Keysar and Navarro-Riviera, 2014), and women make up less than a third of the total number, female atheists constitute a minority within a minority and fewer even actively participate in the organised atheist movement (AAI Gender Balance Report, 2016). ${ }^{2}$ Scholars have suggested that this disproportion may be caused by women's unwillingness to come out

\footnotetext{
2 Most extant surveys ask questions about 'nones' (Brown, 2013: 229), and they rarely break the sub-categories down by gender. The notable exception is atheistcensus.com, an online voluntary survey set up by the Atheist Alliance. For a critical analysis of the methodology and general usefulness of the census, see http://www.brin.ac.uk/news/2013/demographics-of-atheism/
} 
of the atheist closet lest they risk ostracism (Goldstein and Jacoby, 2015; Edgell, Frost, and Stewart, 2017). Meanwhile, the sociological study of atheism and gender remains in its infancy (Mahlamäki, 2012; Eccles and Catto, 2015; Author, 2018). Thus far, the richest available data come from the historical records of organised secularists, otherwise known as Freethinkers (Jacoby, 2004). The movement developed out of the utopian socialist tradition and flourished in the US, Britain, and in Europe throughout the nineteenth century. Freethinkers objected to what they termed irrational religion, and called for a secular government and morality divorced from religious basis. ${ }^{3}$ In the apex of Freethought (18751914), the gender ratio was, unsurprisingly, skewed toward men, although in the US on average around $20 \%$ were female, while in the UK women made up a quarter of the audience at secularist public meetings. However, unlike their male counterparts, Freethinking women juggled a complex set of expectations as a result of rejecting religion: secularism and appropriate femininity had to be balanced because a Freethinking woman's credibility could undermined by 'unfeminine' behaviour. Women who publicly proclaimed atheism were chastised - including being chased and lynched by an angry mob on occasion - and they also risked accusations of sexual immorality (Kolmerten,1999; Gaylor, 1997). Female Freethinkers quickly learned to pick their battles carefully while navigating the gender regime of the period; while in 1830s-40s they happily cohabited with men, in 1870s two of the leading ones were married to avoid the additional stigma of sexual impropriety (Schwartz, 2013: 78). In public speeches, many also emphasized their piety prior to quitting religion to assure the audience of their morality and femininity (Schwartz, 2013). And still, the public reacted with outrage. Descriptions of atheist women in newspapers ranged from 'a thousand times below a prostitute' (Kolmerten, 1999: xvii) to 'Red Harlot of Infidelity' (Snowden McLeod, 2000). The articles about these women began with warnings, such as 'the hearts of your readers will shudder' (Ginzberg, 1994), and male columnists despaired over the new type of woman who 'has forgotten her sex' (Daniels, 1840). In other words, atheist women were not women at all and posed a threat to 'proper' femininity. ${ }^{4}$ This example demonstrates inevitable gendering of atheism whereby women risk more than men by rebelling against the status quo (see also Edgell, Frost, and Stewart, 2017). Women who defy religion, threaten the gender order as they undermine their own feminine nature. Indeed, female Freethinkers hoped for a new type of woman who would be 'a free rover on the broad, bright breezy

\footnotetext{
${ }^{3}$ Internally, the movement varied wildly as it housed atheists, pantheists, deists, agnostics and spiritualists.

${ }^{4}$ See Dyhouse(2014) for examples of the moral panics around femininity since the $19^{\text {th }}$ century to the present day.
} 
common of the universe' (Martineau, 1877: 116), and 'free and fearless, absolutely untrammeled, in thought, word and deed' (Kirkley, 2000: 68-69). In the twenty-first century a large proportion of western women have the freedom to be 'everyday atheists' and experience little to no loss of status or social ostracism but, as evidenced below, atheism continues to be classed as an unfeminine pursuit (Author, 2018).

\section{Atheism and feminism}

In the past decade the atheist movement has been plagued with accusations of misogyny, sexual harassment, and general hostility towards women (Mooney, 2011; Oppenheimer, 2014). Part of the issue is that male atheists see the movement's primary goal as a critique of religion not to be diluted by the feminist agenda female activists often bring with them (Marcotte, 2014). ${ }^{5}$ However, in reality it is practically impossible to separate female atheism from its emancipatory roots. Lack of belief in god has been associated with feminism due to the historical trajectory of the women's rights movement. The fight for women's rights grew out of the socio-cultural context infused with western Christian values whereby gender norms were prescribed, reinforced, and guarded by religious institutions, which in themselves were intrinsically patriarchal. It is no wonder that the most basic form of rebellion against genderbased oppression would be a rebellion against organised religion. Despite that, very few scholarly publications explicitly address the relationship between atheism and feminism. Extant work tends to concentrate on the relative compatibility between religion and the feminist worldview (Ozorak, 1996). In a rare exploration of feminism and atheism, with the former posited as the primary identity, Christine Overall asks 'whether being a feminist also requires that one be an atheist' (2007: 233). Her conclusion is unequivocal: feminists should embrace rationality and evidence-based worldview in lieu of 'surrendering epistemic responsibility' as part of one's belief system (Overall, 2007: 244). Feminist worldview is simply incompatible with a belief system in which women are considered inferior (Overall, 2007: 246). It is logical, and beneficial, for feminists to identify as atheists because the fight for justice and equality is premised on ethical standards [...] independent of God's will' (Overall, 2007: 242).

If we take atheism as the primary identity, however, the picture becomes more complicated due to the aforementioned divisions within the atheist community. The organised atheist movement is internally contradictory with regard to gender (Schnabel et al. 2016). On the one 


\section{The Study}

This article focuses on atheist women's accounts of their relationship with feminism, and their understanding of the impact of atheism on their gendered self-expression. The argument draws on the data from semi-structured, in-depth interviews with twenty self-identified atheist women from the UK (England and Scotland), Australia, the US, and Poland.

Participants for the project responded to adverts looking for for self-identified atheist women. Unlike research conducted in 'ready-made' sites, such as secularist organisations or meeting groups, this method of sampling is problematic due to potential bias inscribed in the process of selecting participants. Purposeful sampling, however, is entirely appropriate where the researcher seeks to interview individuals with a particular characteristic, in this case atheist convictions, in common (Patton, 1990). The sample was non-random and adverts were placed

\footnotetext{
${ }^{6}$ To complicate the matter further, there is evidence that 'men who are more liberal, hold less traditional gender roles, and endorse less right-wing authoritarian values are actually more likely to identify as atheist than their traditionally gendered male counterparts' (Brewster, 2013: 512).
} 
on social media, and message boards in cafes in cities in the four countries. The interviewees came from different cultural contexts, which went some way toward ensuring that the common patterns that emerged could not be solely explained by references to collectively created scripts of the atheist experience. All respondents were city dwellers, and all except one held an undergraduate degree. Seven had doctorates in a variety of subjects, including humanities, social and natural sciences, and theology, which might reflect the positive correlation between higher education and non-belief (Sherkat, 2008). All participants were cis-gender, white, and heterosexual except for one who identified as a lesbian. Four women lived in Australia, eight in the United Kingdom (England and Scotland), four in Poland, and four in the United States. All participants permanently resided in their countries of origin. The youngest interviewee was twenty-eight and the oldest fifty-two. Seven participants had children from heterosexual marriages, and two of those were divorced and raising their children alone. It is possible that these demographic characteristics afforded the interviewees a relatively privileged status in their respective cultures, which meant that they had more choice in expressing their atheism on their own terms.

The project was approved by the Research Ethics Committee at the University of Aberdeen. The participants were provided with an information sheet which outlined the purpose of the study, the interview process, and the right of interviewees to refuse to answer questions, or withdraw their consent at any time. Each participant signed a consent form prior to the interview. The form specified that all information collected during the course of the research would be kept strictly confidential. Consequently, all interview transcripts were anonymised, any identifying information was removed, pseudonyms were used, and all data was password protected and stored securely.

The interviews lasted an hour on average. They were conducted over ten months in 2014, via Skype or in person and digitally recorded. ${ }^{7}$ The emerging themes included reflections on the process of becoming an atheist, everyday life experience (including rites of passage, parenting, professional and personal interactions, and religion in the public sphere), and identification with atheism and feminism. The recordings were transcribed and, where appropriate, translated into English. Each interview was coded holistically as a narrative about living as an atheist woman and later recoded according to emergent themes which were compared across interviews. The sample is relatively small and as such it cannot be used for

\footnotetext{
${ }^{7}$ Skype interviewing comes with its own technological and ethical challenges but it allowed me to overcome the geographical and financial implications of conducting international research (Hanna, 2012; Seitz, 2015).
} 
the purpose of generalisation. My goal is to explore and conceptualise the lived realities of a hitherto under-researched population. No definition of atheism or feminism was offered to the participants in order to maintain flexibility and open-endedness of the interviews. This strategy resulted in variegated narratives on the role of atheism in the reinvention of femininity, and the relationship between atheism and feminism.

\section{Gender, atheism, and feminism}

In a 2013 survey of spiritual or religious views among feminists in the UK, two-thirds of respondents declared themselves atheists, agnostics, or none (Redfern and Aune, 2013: 161). However, feminism and non-belief do not always coincide, and various versions of spiritual and religious adherence have been identified in feminist populations (Aune, 2015; Klassen, 2009). All of the atheist women in this research considered themselves feminists, but their interpretations of the term differed across the interviews. In some cases, it was their feminism, not atheism, which caused trouble in everyday interactions. These interviewees encountered hostility whenever they spoke out 'decisively and unapologetically' about concerns involving gender. ${ }^{8}$ Danielle $(38, \mathrm{UK})$ talked about her personal and professional interactions as she reflected on the various facets of her self-understanding. In everyday life her atheism was often eclipsed by the consequences of overtly stating her feminist convictions: 'my feminism ... I feel I encounter more challenges about saying I'm a feminist than saying I don't believe in any god. ' Another participant, Claudia (29, Australian), suggested that both atheism and feminism were deemed 'unfeminine': 'I would imagine women may not identify as atheists because of being thought of as too challenging, as problematic, troublesome, yeah, calling yourself atheist is political, radical. I'd say it's the same with feminism'. Thus, both atheism and feminism appear to undermine the 'appropriate femininity' of the individual. The stereotypical charge levelled at feminism often rests on the supposed hatred of men and self-hatred, coupled with radical, uncompromising and aggressively presented beliefs (Alexander and Ryan, 1997; Twenge and Zucker, 1999). The threat posed by such unruly femininity has long been the fuel of moral panics (Dyhouse, 2014). For example, the freethinking women of the nineteenth century who fought for freedom from religion, male dominance, and race and class oppression were described as 'the vilest strumpet from the stews' (Kolmerten, 1999: 153) or 'social poison' (Daniels, 1840: 112) by journalists. One cannot help but think of these epithets as the nineteenth century

\footnotetext{
${ }^{8}$ This was the case for the interviewees in all four countries.
} 
versions of 'feminazi', a term used in an attempt to silence outspoken feminist women in the internet era (Cole, 2015; Christina, 2015; Williams, 2015). ${ }^{9}$ Danielle (38, UK) was acutely aware of the stigma and felt caught between the desire to assert her identity and her own unwitting compliance with the unwritten code of appropriate feminine behaviour. She explained that in the past she described herself as 'post-Christian' instead of 'atheist' because 'somehow the term post-Christian is softer, it's not quite the hard and fast distinction as atheist. It's a bit like with being a feminist because for a long time I was doing the "I'm not a feminist but" then.'

Danielle was one of the four interviewees who made an explicit connection between atheism and feminism. Megan (38, US), a member of an informal feminist book group, also thought that feminism and atheism were inextricably linked. According to her, 'a religious woman could never be a feminist. Atheism is a belief in yourself as opposed to anything else. It's also linked to humanism. It's not about religion, it's not about sexuality, it's just about human beings. I don't think you can be a religious person and hold this viewpoint.' Valerie (40, UK), the third participant to make the connection, looked visibly annoyed when I tentatively broached the possibility of combining religious identity with feminism: 'Oh, I'm sure there are many Muslim academic women who reconcile them but I don't know how. I can't imagine it. It comes down to: 'we're not equal, you're a whore, you're a virgin, you're a rib, you're a secondary person, without a doubt, so I don't know how you accept that, the dismissal of your gender'. Amelia (40, UK) could not see any redeeming qualities in religion, either. For her, the connective tissue between atheism and feminism comprised logic and rationality: 'because atheism is logical and so is feminism. So it's about rationality of life, it's a logical pursuit. It makes no sense that women are treated differently from men whatsoever. And in the same way, it makes no sense for me that God exists'. But Candice (39, Australia) held a more nuanced perspective: 'I think you can still be religious and be a feminist. It's like you can be homosexual and a Catholic. And to identify as both, even though they're seemingly at odds with each other, so you might choose to fight it within the church.'

As a noun and an adjective, 'feminist' remains a controversial and highly contested term. In the age of fluid identities and the growing resistance against clear-cut labels among the millennials, the adjective carries with it similar implications to those of 'atheist'. The phrase 'I'm not a feminist but...', alluded to by Danielle, reflects this trend to some extent but those

\footnotetext{
${ }^{9}$ The Oxford Dictionary of American Political Slang defines feminazi as both 'a committed feminist' and a 'strong-willed' woman (Barret, 2006: 105).
} 
uttering it are usually aware of the underlying paradox (Moi, 2006). While all of my participants clearly identified as atheists, their relationship with the feminist label was more ambiguous. Ultimately, at some point during the interview, all of the women claimed feminist convictions, albeit they arrived at them through different narrative means. When asked about her self-identification, Naomi (39, UK) thought for a few seconds before nodding her head: 'Yes, I would describe myself as a feminist...for many years now, even though I don't like to label things, but yes. And my husband would DEFINITELY describe me as a feminist.' She drew on her husband's perception of herself to bring the label into being, but also distanced herself from categorising identities in a definitive manner. Like several other interviewees, Naomi did not stop there, but elaborated on her personalised definition of feminism:

'for me it is all about women being able to make their own choices and live their lives in their own way and not being restricted because of gender. That's how I see it. So it's not aggressive, but just because you're female you shouldn't explain yourself or justify yourself, or get paid less or that kind of crap.'

In this passage Naomi domesticated feminism. In light of her knowledge of how feminism is judged by an average person, she emphasised the non-aggressive nature of her feminist stance. This reading is redolent of the masculine rhetoric which often distinguishes between good and bad feminists where the latter are hysterical and irrational (Edley and Wetherell, 2001). Naomi and most other interviewees opted for practising 'reasonable feminism' (Calder-Dawe and Gavey, 2016) marked by calm, rationality, evidence, and clarity. Meanwhile, for Amelia (40, UK) adopting the feminist label was more straightforward and did not involve such negotiation. She emphatically stated: 'if you're a woman and if you don't [call yourself a feminist], there's something wrong...' An Australian, Shannon (29), was 'for feminism because I obviously believe in gender equality'. But another Australian, Debra (33) phrased her answer more cautiously: 'Probably. Yes, probably but it's quite difficult because we live in a very equal world now. It's very rare that you don't...It's across the board, it's equal, it doesn't matter if you male or female...'. While she did not see the need for overt identification with feminism, in the course of the interview she recalled instances when her female status meant she was excluded from certain situations, ostensibly for her own good. A scenario which stuck in her mind was when a coach in her school's sports club asked the girls to step out when he was giving his motivational speech to the boys as it contained swear words. She recalled: 'I thought, look, if I take offence I will stay out of the room, but it should be my choice, not because I'm female'. Debra understood this 
experience in individual, not structural terms, however. Moreover, she took the view that boys are neglected in schools due to the exclusive focus on female empowerment. Her own teachers taught her how to stand up against bullying from the boys when, in reality, 'the bullying came more from other girls'. Debra combined two assumptions about feminism, both of which echo the popular critique of feminist activism in the postmodern era. First, gender equality has been achieved, which makes feminism irrelevant (Ringrose, 2007). And second, feminists fail to see that their excessive focus on female empowerment both disadvantages boys and men and protects the real culprits in the playground who are often other women. In this sense, feminism is not egalitarian.

Candice (39, Australia) had a more nuanced relationship with feminism. Her non-committal attitude stemmed partly from her autobiography:

'I've never really identified with feminism because I come from the era when it was a really strong movement that had to make the changes in the seventies and you were either a marching in the streets a feminist, or you weren't one at all. I assumed that we'd got to gender equality and it's only in the past few years, and only really since the Gillard government that it became part of my psyche and I would identify with feminism more because her government showed that there is a lot of underlying and not spoken about and deeply embedded sexism or even misogyny. ${ }^{10}$

While Debra believed equality had been achieved, Candice discovered the opposite was the case. Her return to feminism was sparked by a realisation that the supposed gains of the feminist movement were uneven and misogyny sprang up unexpectedly in public debates. She attributed her epiphany to the process of aging and crystallising her idea of what feminism was as she became aware of the subtle ways in which inequalities persisted in everyday life. However, and most importantly, she saw her feminism in terms of an ongoing discussion, support for other women in her profession, and developing tools for addressing the micro issues she identified through experience and observation. Candice was not interested in 'joining any marches', but she spoke passionately about 'learning how to break down barriers around promotion and getting women into science degrees'. She developed a keen interest in the self-help literature for professional women and cited motivational

\footnotetext{
${ }^{10}$ Julia Gillard is the former Australian Prime Minister (2010-2013). She was the first ever woman in the role and her term was marked by gendered media coverage where the focus was on Gillard's private life instead of her politics (Stevenson, 2013). Gillard is also an 'out' atheist, she is not married, and does not have children, all of which became the subject of media interest.
} 
bestsellers such as 'Nice Girls Don't Get the Corner Office' (Frankel, 2004) and 'Lean In' (Sandberg, 2013). Both books have been criticised for ignoring structural barriers, and instead blaming women themselves for their lack of success but Candice found them relatable: 'Not that I want to be like a man but it's good to realise what mistakes we, as women, make and how to approach work differently.' Alice (35, UK) also experienced a conflicted relationship with feminism:

'Yeah, I am, I am [a feminist]. I dip in and out of it. Sometimes I feel really strongly about it and sometimes I feel that I don't like the way some of the feminist campaign and movement is going. Some if it is detracting from some of the real issues that we have as women, much more serious than whether there's a pair of boobs in the paper. And for me, women's magazines are so much more harmful than page 3 of the Sun.'

Alice highlighted another reason why women's magazines do more harm than a 'pair of boobs'. Women's magazines 'are by women for women and they're so critical and oppressive, and patronising! They have no role models for women beyond patronising bullshit.' When I mentioned potentially empowering articles and asked whether the return of feminism to the front pages of women's magazines could be a force for good, Alice snorted: 'the feminist movement seems taken over by the selfie thing, it's like a clever campaign, marketing, but it's completely missing the point.' Another participant, Amelia (40, UK), was puzzled by both the feminist movement and the atheist movement. Like Candice, she did not want to 'join any marches' and she saw both as 'just another form of organised religion. I don't really see the point of it.' Secular feminism can be associated with the critique of religion, and indeed, the impetus for change has historically been tied up with the objection to divinely-sanctioned subjugation of women. However, only two of my participants depicted feminism as a reaction against religious tradition. Valerie (40, UK) jokingly referred to 'all the nonsense with Adam and Eve' and Danielle (39, UK) spoke at length about the stroke of realisation when she heard about Phyllis Trible's 'Texts of Terror' (1984) where the author deconstructs the Bible through a feminist analytical lens and demonstrates the extent of violence against women in holy texts. While the participants differed in their accounts of feminism, they unanimously cited 'strength' as a concept which best defined them as individuals.

\section{Atheist women and strength}


Physical weakness and economic dependency are the two chief characteristics in traditional stereotypes of femininity. Despite the gains of the women's movement and the now takenfor-granted 'having it all' mentality, combining the domestic and professional realms remains challenging for the twenty-first century woman, as expectations rise in both spheres (Rottenberg, 2014). The Freethinkers of the nineteenth century had high hopes for the 'superwoman' of the centuries to come. This first 'true woman' woman would be driven by a 'rational and realized ego' and develop 'powers of heart to feel for, to pity and to love' (Kirkley, 2000: 72-73). Unfortunately, Freethinkers were overly optimistic about organic developments in this realm and did not translate their predictions and hopes into a full-blown societal reforms, which contributed to the present-day dilemmas women face (Kirkely, 2000: 74). Individualism and rationalism were at the centre of the secular social order Freethinkers envisioned, but the reality has turned out to be messier and the change uneven and fraught with contradictions and practical difficulties. A theme which exemplifies this confusion well is 'strength'. The atheist women in this study used the term 'strong' and 'strong-minded' to signal a departure from 'proper femininity' (Oksala, 2013), but also to distance themselves from what they saw as masculine behaviour. They described strong women as those who speak their mind and face public judgment as a result. Several participants cited public criticism of Hilary Clinton's 'angry' style (Feldman Barrett, 2016), the 'leg gate' featuring Theresa May and Nicola Sturgeon (Stone, 2017), the photo coverage of female athletes, and rampant misogyny in the boardroom as clear evidence that the cultural expectation of 'proper femininity' is alive and well. As Bogna (29, Poland) said: 'it's only ever okay for a woman to be strong when it suits other people, like when someone needs looking after.' Women are allowed to display strength in situations which fit in with the gender-appropriate sphere, such as caring for others and providing emotional support in times of interpersonal crisis. Still, the relationship between femininity and strength remains a conflicted one. ${ }^{11}$ Strength understood as assertiveness can be disadvantageous for a woman, as the examples above demonstrate.

And yet, strength featured as the recurring theme in my interviewees' narratives. For example, Valerie $(40, \mathrm{UK})$ told me that men thought of her as formidable and intimidating, hence not many challenged her: I do have quite a dominant personality and I say things with

\footnotetext{
11 'Strength' is not only gendered but also racialized. The richest body of literature on the discourses of strength and femininity comes from feminist scholars who specialise in race and gender. For example, 'being strong' is a culturally specific expectation placed on Black women which casts them as 'stark and deviant opposites of weak and appropriately feminine white women' (Beauboeuf-Lafontant, 2007: 31). For white women 'being strong' can be used to cast their femininity into question, both on the mental and a physical level.
} 
a degree of assuredness that doesn't invite people [to question my views]. She took pride in the readiness to stand up for her beliefs and appreciated her freedom to do so. She saw it as her duty as a woman and an atheist to speak out 'without the fear of being stoned to death, literally murdered. Which actually makes me think it's all the more important that I do it. Much like voting. ' For Naomi (39, UK), however, being outspoken caused problems at work. She identified as a feminist, but she rarely described herself explicitly in these terms. Instead, she was more likely to define herself as

'a strong and powerful woman who goes out there and helps other women to find their chance to get out. I speak my mind and I don't care where I am. Not in a rude and disgusting way but I'll say what I think. My former boss, he was male and...terrible. He didn't like strong women at all.'

Naomi presented strength as a positive quality but it can be a derogatory term when used by a male superior in relation to a female employee. ${ }^{12}$ The scenario where a male boss used the term 'strong woman' turned out to be a relatively common one among my participants. For example, Kora (37, Poland) wondered why it was that ' when I do express my opinions I am seen as strong-minded? What does my boss say about me? Strong-minded. Rather than just being a smart person, you know, I'm described as a strong-minded woman instead.' Another interviewee, Karen (33, UK), went further to decipher the meaning of the phrase as it was frequently applied to her: 'so just because I say what's on my mind, this guy at work introduced me as a 'strong woman' to a new colleague. It made me angry because he'd never say it about a man!'

These interview extracts demonstrate both the interviewees' attempt to challenge the silencing of women, and the resistance they encounter when doing so. 'Strong women' are implicitly labelled as outside normative femininity and their strength is considered an oddity. Nina (31, Poland) summed up the situation succinctly when she remarked: 'the problem is not being an atheist woman, I think the problem is being a woman [laughs]'. As evidenced above, atheist identity, while not necessarily tied up with feminist views, acted more as a background to gender. Alice (35, UK) echoed Nina's sentiment almost word by word when she said: it's not a problem being an atheist woman. Being a woman, now that is definitely more problematic.' 
Gloria (52, Australia) illustrated her narrative of strength with an example of what happens to women who do not conform to social expectations when she discussed the aforementioned case of the Australian former Prime Minister, Julia Gillard. In 2012 Gillard delivered what has become known as the 'Misogyny Speech' in which she castigated her political opponent, Tony Abbott, for sexism and misogyny. ${ }^{13}$ Gloria saw the subsequent public reactions to the speech as the prime example of how punishment is meted out to women in leadership roles who 'crack and call it [sexism] what it is'. She analysed the episode in detail:

Yeah, yeah, it was her downfall because my perception is that she was a strong woman that kept her cool in so many situations and put up with that shit all the time. Then she spoke out and she was labelled as an even more aggressive female and how dare she? The personal vitriol that came out about Julia Gillard, and calling her a liar and the horrible stuff that people would say about her, using awful words, so yes with the male prime minister people would attack his policies but not attacking him personally.

This extract exemplifies the key finding in this study. Participants started out by discussing their own atheism but almost inevitably drifted towards issues of gender and inequality, particularly in the context of the public sphere. For example, Anna (35, US) valued her affinity with other women over her bond with other atheists. She saw herself as a 'girls' girl so I identify with women first and atheists second. And a lot of atheists tell you that atheism is about nothing else but not believing in God and that feminism has no place in atheism. I have no time for it because I will always fight for women first'. While Gloria's analysis of what happened to Gillard is specific to politics, the theme of a 'strong woman being put in her place' travels easily into the more mundane life situations. All of the interview data above highlights the apparent cultural anomaly of associating strength with a woman, but another reading is also possible. The cultural definition of strength is itself gendered: the men cited above used the phrase dismissively to discipline unruly women, while the female participants used it to describe themselves in empowering terms. This empowerment, however, is not simply psychological and individualistic. As we discussed atheism, religion, and everyday life in more general terms, Shannon (29, Australia) also referred to herself as a strong woman. When asked to elaborate on the kind of situation where she would act it out, she paused for a minute and then slowly said:

\footnotetext{
${ }^{13}$ The speech received praise outside of Australia but the reactions in the country were mixed and Gillard was accused of playing the 'gender card'. The full transcript of the speech can be found here https://www.smh.com.au/politics/federal/transcript-of-julia-gillards-speech-20121010-27c36.html
} 
Only if people use religion to marginalise somebody else. Or me, yeah. So I'm happy for everyone to believe what they want to believe but if you try to use that belief to marginalise somebody else, or me, then that's when I would be strong enough to stand up against that.

Shannon understood her strength as a force for collective good. Her own sense of empowerment motivated her to stand up for others, rather than simply for herself. In this case, atheism stands for empathy and solidarity, rather than selfishness and immorality atheists are sometimes charged with (Gervais et al. 2017; Edgell et al. 2016; Hammer et al. 2012). At the time of the interview Megan (38, US) and her husband were considering starting a family, which for her meant a heightened awareness of gendered socialization and the need for her own daughters to be raised as 'strong women'. Megan, however, qualified the meaning of the phrase as follows: 'I feel quite strongly about bringing up girls to think that they can be assertive and confident. Not aggressive though, I don't think anyone should be aggressive.' The qualification reflects the emerging tendency identified by feminist scholars (Adamson, 2017) whereby women balance feminine and masculine behaviours in order to fit into the neoliberal mould of a successful femininity. Atheist female subjectivity incorporates the postfeminist discourse of independence, strength (or empowerment), and freedom of choice, but it is inevitably framed by the softening measures required to retain the 'reasonable' and 'balanced' persona. Megan, like several other participants, was acutely aware of the internal contradictions, but justified her narrative thus: "nothing good can come out of aggression, and self-delusion. It's actually not that productive and frankly, I find it offputting'. Like Natalie (39, UK), she rejected aggression and embraced assertiveness and confidence instead.

\section{Conclusion: balancing femininity, feminism, and atheism}

The main goal of this article is to analyse the relationship between atheist and feminist identification in the narratives of self-identified atheist women. The central argument emphasizes the role of atheism as a background identity marker through which female subjectivity is enacted in everyday life. I identify two key themes: first, atheism and feminism are both devalued identities when embraced by women; and second, identifying as an atheist affords the participants an impetus to invent a new vocabulary to account for their identity. In doing so, they engage in a balancing act of domesticating atheism and feminism, and neutralising the perceived threat both (but mostly the latter) might pose to the public gender regime. Atheist women create narratives which offset both their atheism and their feminism 
as they distance themselves from aggression. This finding resonates strongly with the argument by Edgell et al. (2017) who argue that atheism can be socially risky for women. Risk awareness makes women less likely to identify with atheism and when, like the participants in this research, they subscribe to both atheism and feminism, they adjust their utterances and actions so as to minimise the social risks involved. While the women in this study did not feel that their atheism incurred social costs, they thought feminism did, and they modified the language they used to come across as 'reasonable' and 'non-aggressive'.

The participants' accounts are heterogeneous and internally contradictory. The women in this study practised a form of 'balanced atheism'. On the one hand, they dissociated from what they saw as aggressive, masculine, and intellectually arrogant rhetoric espoused chiefly by New Atheism (Beattie, 2013). They did not attack religion unprovoked, but they reacted against perceived discrimination and injustice, whether driven by religious or secular misogyny. On the other hand, though they identified with rationality and scientism to some extent, they redefined both concepts to fit with their gendered perspective of the world. In this perspective, feminism appears higher than atheism in the hierarchy of devalued identities because the former is more stigmatised than the latter. Feminism and atheism mostly feature as separate entities, connected by the phrase 'strong woman'. For these women strength indexes self-belief, independence, empowerment, and a defiant attitude to traditional gender roles. However, adopting the term 'strong' inevitably contributes to the enactment of 'balanced femininity' (Adamson, 2017), a stance incompatible with committed feminism and aggressive atheism; both are classed as 'over the top' and 'too much'. The participants distanced themselves from such extreme behaviours and emphasized rational and reasonable approach as the ideal. Their strategies are reminiscent of the postfeminist discourse (Gill 2007; McRobbie 2009) which prioritises 'nice' assertiveness in pursuing one's life goals over the angry confrontational style of the 'unbalanced' feminist. In this sense, the atheist women subscribed to the rules of rationality, self-control, and responsibility. 'Unreasonable feminism', understood as outdated, unfeminine, aggressive, and selfish (Calder-Dawe and Gavey, 2016), was uniformly dismissed but, just like the male atheists in Stinson et al.'s (2013) study, atheist women displayed a wide range of attitudes toward feminism, including a concern about the place of men in the debate.

To reiterate the main point of this article, in the twenty-first century atheism provides the catalyst for women to assert their individualism, to express their views, and to object to social injustice, including gender discrimination. One possible reading of the findings suggests that 
adopting an atheist identity fulfils the Freethinkers' projection of the future woman as 'the empress of her intellect and heart' who will not 'be fettered by no senseless formula or puerile dogma' (Kirkley, 2000: 68-69). Another, less optimistic interpretation highlights the self-governing efforts of atheist women, including careful modification of their agency to achieve the neoliberal ideal of balanced feminism, femininity, and atheism. All three identity components are best practised in moderation, and as a result they protect the balance of the gender regime in which unlimited choice and individualism may pose a threat to the status quo. These strategies amount to what some have described as 'choice feminism' (Hirschmann, 2006) where femininity is defined by freedom of choice, individualism and empowerment. As demonstrated clearly in the atheist women's accounts of religious and secular misogyny, the individualised sense of freedom clashes with the objective experience of the public gender regime. Their narratives embody the paradox of choice feminism whereby women's choices are inevitably made in the context of pre-existing social conditions which frame them from the outset (Ridgeway, 2011). The systemic framework obstructs certain femininities and enables the ones more amenable to the dominant expectations. What makes atheist women in this study unique is their ability to combine elements of choice feminism with what Angela McRobbie refers to as 'an angry and outright critique of male domination' (2015: 17). Thus, the participants did not fully engage in the 'post-feminist masquarade' where women self-govern instead of critiquing male privilege (McRobbie, 2015: 8). Instead, atheist identification places these women in a position to recognise and question male domination from a different vantage point to this of committed (post)feminists. Consequently, women's lived experience of atheism intersects strongly with their gendered interests, which gives a distinct shape to their feminist worldview.

\section{References}

AAI Gender Balance Report (2016). Accessed January 16, 2018. https://www.atheistalliance.org/userdata/documents/AAI_Gender_Balance_Report.pdf

American Secular Census 2013

Adamson, M. (2017). Postfeminism, Neoliberalism and A 'Successfully' Balanced Femininity in Celebrity CEO Autobiographies. Gender, Work\& Organisation, vol. 24 (3): 314-327.

Alexander, S., \& Ryan, M. (1997). Social constructs of feminism: A study of undergraduates at a women's college. College Student Journal, 31, 555-567. 
Anderson, V.N. (2009). What's in a Label? Judgment of Feminist Men and Feminist Women. Psychology of Women Quarterly, 33: 206 - 215.

Aronson, P. (2003). Feminists or "postfeminists"?: Young women's attitudes toward feminism and gender relations. Gender \& Society, 17(6), 903-922.

Aune, K. (2011). Much Less Religious a Little More Spiritual: the Religious and Spiritual Views of Third-Wave Feminists in the UK, Feminist Review, 97: 32-52.

Aune, K. (2015). Feminist Spirituality as Lived Religion: How UK Feminists Forge Religiospiritual Lives. Gender and Society, 29(1), 122-145.

Aune, K., Sharma, S., and Vincett, G. (2008). Women and Religion in the West: Chalenging Secularization. Aldershot: Ashgate.

Barret, G. (ed.) (2004). The Oxford Dictionary of American Political Slang. Oxford University Press.

Beattie, T. (2007). The New Atheists. The Twilight of Reason and the War on Religion. London: Darton, Longman and Todd.

Beit-Hallahmi, B. (2007). Atheism: a Psychological Profile. In Michael Martin (ed.), The Cambridge Companion to Atheism. Cambridge: Cambridge University Press. pp. 300-317.

Beauboeuf-Lafontant, T. (2007). "You Have to Show Strength". An Exploration of Gender, Race, and Depression. Gender\& Society, vol. 21, no. 1: 28-51.

Budgeon, S. (2015). Individualised Femininity and Feminist Politics of Choice. The European Journal of Women's Studies, vol 22, no. 3, pp. 303-318.

Calder-Dawe, O. and Gavey, N. (2016). Jekyll and Hyde revisited: Young people's constructions of feminism, feminists and the practice of 'reasonable feminism'. Feminism\& Psychology, vol. 26 (4): 487-507.

Christina, G. (2012). "\#mencallmethings: 'FUCKIN HOE,' 'FUCKIN FEMINAZI SLUT."” Greta Christina's Blog: Atheism, sex, politics, dreams, and whatever, August 8. Accessed March 18, 2018. https://the-orbit.net/greta/2012/08/24/mencallmethings-fuckin-hoe-fuckinfeminazi-slut/

Cole, K.K. (2015). "It's Like She's Eager to be Verbally Abused": Twitter, Trolls, and (En)Gendering Disciplinary Rhetoric, Feminist Media Studies, 15:2, 356-358.

Daniels, C.F., 1840. 'Female Irreligion.' The Ladies' Companion, vol. 13, p.111-113.

Dyhouse, C. (2014). Girl Trouble. Panic and Progress in the History of Young Women. London: Zed Books.

Eccles, J and Catto, R 2015 Espousing Apostasy and Feminism? Older and Younger British Female Apostates Compared. Secularism and Nonreligion, 4(5), 1-12.

Edgell, P., Frost, J. and Stewart, E. (2017). From Existential to Social Understandings of Risk: Examining Gender Differences in Nonreligion. Social Currents, 1-19. 
Edley, N., \& Wetherell, M. (2001). Jekyll and Hyde: Men's constructions of feminism and feminists. Feminism \& Psychology, 11(4), 439-457.

Feldman Barrett, L. (2016). Hillary Clinton's ‘Angry’ Face. The New York Times, 23 Sept. Accessed Jan 23, 2018. https://www.nytimes.com/2016/09/25/opinion/sunday/hillaryclintons-angry-face.html

Frankel, L.P. (2004). Nice Girls Don't Get the Corner Office. 101 Unconscious Mistakes Women Make to Sabotage Their Careers. New York: Warner Books.

Gaylor, Annie Laurie, ed (1997). Women Without Superstition: "No Gods - No Masters". Madison, WI: Freedom from Religion Foundation.

Gervais, W.M. et al. (2017). Global evidence of extreme intuitive moral prejudice against atheists. Nat. Hum. Behav. 10151

Gill, R. (2007). Postfeminist media culture: elements of a sensibility. European Journal of Cultural Studies, 10 (2):147-166.

Ginzberg, Lori D. 'The Hearts of Your Readers Will Shudder': Fanny Wright, Infidelity, and American Freethought.” American Quarterly, Vol 46, No. 2, (1994): 195-226.

Goldstein, R. and Jacoby, S. (2015). Why Women Are Too Polite About Religion. Women in Secularism III. Reasonable Talk. Accessed February 9, 2018. https://reasonabletalk.tv/whywomen-are-too-polite-about-religion/

Hammer, J. H., Cragun, R. T., Hwang, K., \& Smith, J. (2012). Forms, frequency, and correlates of perceived anti-atheist discrimination. Secularism and Nonreligion, 1, 43-67.

Jacoby, S. (2004). Freethinkers: A History of American Secularism. New York: Owl Press.

Keysar, Ariela and Juhem Navarro-Rivera. "A World of Atheism: Global Demographics.” In The Oxford Handbook of Atheism, edited by Stephen Bullivant and Michael Ruse, 553-587. Oxford: Oxford

Kirkley, E 2000 Rational Mothers and Infidel Gentlemen: Gender and American Atheism, 18651915. NY: Syracuse University Press.

Klassen, C.A. (ed.) (2009). Feminist Spirituality. The Next Generation. Plymouth: Lexington Books.

Kolmerten, Carol. American Life of Ernestine Rose. New York: Syracuse University Press, 1999.

Lee, L. (2012). Talking About a Revolution: Terminology for the New Field of Nonreligion Studies. Journal of Contemporary Religion, 27 (1), 129-139.

Mahlamäki, T. (2012). Religion and Atheism from a Gender Perspective. Approaching Religion, (2) 1, 58-65.

Marcotte, A. (2014). Atheism's shocking woman problem: What's behind the misogyny of Richard Dawkins and Sam Harris? Salon 10.03. Accessed March 22018 
https://www.salon.com/2014/10/03/new atheisms troubling misogyny the pompous sexis $\underline{m}$ of richard dawkins and sam harris partner/

McRobbie, A. (2009). The Aftermath of Feminism: Gender, Culture and Social Change, London: Sage Publications.

McRobbie, A. (2015). Notes on the Perfect, Australian Feminist Studies, 30:83, 3-20

Moi, T. (2006). “I am not a Feminist, But...”: How Feminism Became the F-Word. PMLA, $121(5): 1735-1741$.

Mooney, C. (2011). The Future of Irreligion, Part 2: A Conversation with Barry A. Kosmin, Free Inquiry, 31/8, 44.

Oksala, J. (2013). Feminism and Neoliberal Governmentality. Foucault Studies, No. 16: 32 53.

Oppenheimer, M. (2014). Will Sexism Bring Down the Atheist Movement? Buzfeed, Sept 12. Accessed Jan 172018 https://www.buzzfeed.com/markoppenheimer/will-misogynybring-down-the-atheist-movement?utm term=.sknBwgn6Q\#.gcnENg7nw

Overall, Christine. "Feminism and Atheism." In The Cambridge Companion to Atheism, edited by Michael Martin, 233-250. Cambridge: Cambridge University Press, 2007.

Peltola, P., Milkie, M. A., \& Presser, S. (2004). The "feminist" mystique: Feminist identity in three generations of women. Gender \& Society, 18, 122-144.

Pew Forum 2015 America's Changing Religious Landscape

Report. http://www.pewforum.org/2015/05/12/americas-changing-religious-landscape/._.

Pew Research Center 2016 The Gender Gap in Religion Around the

World. http://www.pewforum.org/2016/03/22/the-gender-gap-in-religion-around-the-world/._-

Redfern, K. and Aune, K. (2013). Reclaiming the F Word: feminism Today. London: Zed Books.

Ridgeway, C. (2011). Framed by Gender: How Gender Inequality Persists in the Modern World. New York: Oxford University Press.

Ringrose, J. (2007). Successful girls? Complicating post-feminist, neoliberal discourses of educational achievement and gender equality. Gender and Education, 19(4), 471-489

Rottenberg, C. (2013) The Rise of Neoliberal Feminism, Cultural Studies, 28:3, 418-437

Sandberg, S. (2013). Lean In: Women, Work, and the Will to Lead. New York: Alfred A. Knopf.

Sang, K.J.C. (2018). Gender, ethnicity and feminism: an intersectional analysis of the lived experiences feminist academic women in UK higher education, Journal of Gender Studies, $27: 2,192-206$.

Schnabel, L., Facciani, M., Sincoff-Yedid, A. and Fazzino, L. (2016). Gender and Atheism: Paradoxes, Contradictions, and an Agenda for Future Research. Annual Review of the Sociology of Religion: Sociology of Atheism, vol. 7 
Sherkat, D., 2008. Beyond belief: Atheism, agnosticism, and theistic certainty in the United States. Sociological Spectrum, 28(5), 438-459.

Snowden McLeod, S. (2000). 'The Red Harlot of Infidelity': the Life and Works of Frances Wright. Texas Woman's University.

Stevenson, A. (2013). Making gender divisive: 'Post-Feminism', sexism and media representations of Julia Gillard. Burgmann Journal, 1 2: 53-63.

Stinson, R., Goodman, K.M , Bermingham, C., Rasheed Ali, S. (2013). Do Atheism and Feminism Go Hand-in-Hand?: A Qualitative Investigation of Atheist Men's Perspectives about Gender Equality. Secularism and Nonreligion, 2, 39-60

Stone, J., (2017). Daily Mail formally reported to press regulator over 'Theresa May and Nicola Sturgeon's legs' front page. The Independent. 28 March.

Trible, P. (1984). Texts of Terror: Literary-Feminist Readings of Biblical Narratives. Minneapolis: Fortress Press.

Twenge, J. M., \& Zucker, A. N. (1999). What is a feminist? Closed and open-ended responses. Psychology of Women Quarterly, 23, 591-605.

Walby, S. (2011) The Future of Feminism. Cambridge: Polity.

Williams, Z. (2015). 'Feminazi: the go-to term for trolls out to silence women'. The Guardian, Tue 15 Sept. Accessed $15^{\text {th }}$ Jan 2018.https:/www.theguardian.com/world/2015/sep/15/feminazi-go-to-term-for-trolls-out-tosilence-women-charlotte-proudman

Zuckerman, P. (2008). Society without God. New York: New York University Press.

Zuckerman, P. (2009). 'Atheism, Secularity, and Well-Being: How the Findings of Social Science Counter Negative Stereotypes nd Assumptions.' Sociology Compass, 3 (6): 949-971. 